\title{
Élménymorzsák az 50 éves Magyar Endokrinológiai és Anyagcsere Társaság történetéhez
}

\author{
Hankiss János dr.
}

\author{
A gyógyitó orvosok, kutatók nemcsak \\ szakemberek, emberek is: sérülékeny \\ lények, egyéni gondokkal, reményekkel \\ és sorssal. Ugyanúgy, mint bárki más, aki \\ hozzájuk fordul, és erôt, biztatást vár attól, \\ aki maga is küszködik elégtelenségével és bajaival.
}

Életünk munkából, eredményekből, kudarcokból, sikerecskékből és élményekből tevődik össze. Az orvos is eltünik egyszer: jó, ha mindnyájan leteszünk egy maradandó emléket, egy közös élményt róluk, hogy megmaradjanak.

Fornet professzor úr és Hetényi professzor úr tisztelte egymást, így a debreceni és a szegedi klinika minden évben találkozott, hol itt, hol ott. A vendégprofesszor tartott élvezetes és magas szintű elöadást, mi pedig ismerkedtünk egymás munkájával. A Hetényi-klinika már akkor specializált részlegekből tevődött össze, magas szintû tanársegédi-adjunktusi vezetésekkel. Kiváló kollégákkal ismerkedtünk meg, végignéztük osztályrészeiket, kérdezgettük munkamódszereiket. Sőt Kelemen adjunktus úr még teniszpartira is kihívott. Hogy ki nyert, nem emlékszem, de azt hiszem, ő megelőzött. Később, amikor a párizsi Pasteur-intézet professzorától kapott meghívás után hazatértem (ott ADH-inaktiválásos metodikám külföldi közleménye alapján kellett a kalcitonininaktiválást vizsgálnom, ez nagyon nehéz körülmények között sikerült is), Petrányi professzor felajánlotta, hogy szervezzek a klinikán endokrin osztályt. Ezt nem vállaltam, mert a laboratóriumi hormonvizsgálatokra a klinika még nem készült föl, tökéletlen munkát pedig nem óhajtottam végezni. Felmerült a kérdés, a megváltozott klinikámon maradjak-e? Julesz professzor úrhoz fordultam tanácsért, akit nagyra becsültem és bölcsességére számítottam. Meg is kaptam a választ (amely napjainkban szintén hasznos lehet sokaknak): „Ha egész életedre a klinika másodembere akarsz lenni, maradj. Ha önállóságra vágysz, pályázz meg egy jó kórházi állást!" Így kerültem Győrbe, ahol a klinika még nem vezetőségi tagságom révén nagy ellenállás ellenére sikerült egy izotóplabort megszervezni, amely máig kiválóan dolgozik. Ez után a szó legszorosabb értelmében átcsábított ${ }^{1}$ az ország akkor egyetlen oktató kórházába, a Markusovszky Kórházba, ahol nagyszerü szakemberek gyúltek össze (Baltaváry, Kádas, Cholnoky, István Lajos, Széll Kálmán és folytathatnánk az orvosgárdával), és magas színvonalú munka folyt. Minek köszönhető a kórházi munka sikere? Annak, hogy ott mindenki tudta, eredményt csak teammunkával, a tudás összeadásával, egymás segitésével lehet elérni.

Az osztály modernizálása nagyszerú orvosok segítségével sikerülhetett: Az Orvostovábbképző Intézetből Mosonyi professzor úr, Strausz professzor úr, Antalóczy professzor úr és nagyszerü munkatársai rendszeresen látogattak le hozzánk továbbképzésre, illetve ők és a Kardiológiai Intézet, valamint Bozsóky professzor úr a Reumatológiai Intézetben fogadta orvosainkat. Nekik köszönhető, hogy kialakíthattuk a kardiológiai, szubintenzív, peritoneális dialízis, reumatológiai speciális osztályrész mellé az endokrinológia és diabetológia részlegünket a náluk képzett orvosainkkal.

Magyar professzor úr abszolút nagyvonalú segítségérôl, konzultációiról más helyen ${ }^{2}$ már beszámoltam, ugyanúgy, mint tanítómestereimről és példaképeimről is $^{3}$.

Góth Endre tanár urat az endokrinológia révén ismertem meg, előbb a Margit Kórházban, majd a János Kórházban. Nem tudom, szabad-e a tudománytól ennyire elszakadni, de egy történetet azért elmondanék. Amikor Párizsban sikerült befejeznem a munkámat, és elfogadták az erről írt disszertációt, amelyért az „Assistant Étranger des Hôpitaux de Paris" tudományos címmel tüntettek ki, Marseille-be utaztam tapasztalatcserére. Az, hogy a

\footnotetext{
Lemondtam, de pont akkor mentem továbbképzésre a Szegedi I. Belklinika Endokrin Osztályára, és ottani barátaim (László Ferenc, Szarvas Ferenc, Julesz János) rám rontottak és elmondtak mindennek, hogy az ország legkiválóbb kórháza meghívását el kell fogadni. Így aztán tettem, amit az okosabbak tanácsoltak.

A Debreceni I. Sz. Belklinika története: Visszanézve és visszavágyva, DE OTEC 2014 és Barangolás Emlékek Sürújében, Randevú elmúlt önmagunkkal és egy korral, Magyar Tudománytört. Int. 2015. dec.

Fornet, Végh Pál, Kettesi, Endes, Kulin, Ádler, Szeleczky professzoraim, Rombányi prof.
} 
párizsi nagyképű ridegség után az ottani baráti légkör mit jelentett nekem, egyik könyvemben megírtam.

Ottlétem 2-3. napján egyszerre megjelent Góth tanár úr a feleségével, akiknek nagyon megörültem. De ő nagyon rossz hangulatban jött egy kongresszusra, mert autójával valami kisebb karambolt éltek át. Megkért, nem vezetném-e az autójukat Párizsig. Nekem ugyan megvolt a vonatjegyem, és nem nagyon voltam tisztában a francia útszabályokkal, természetesen nem utasíthattam vissza. Így együtt utaztunk a kongresszus után, szerencsére minden baj nélkül Párizsig. Nem telt bele egy nap, fölhívott, hogy szerzett négy jegyet a Moulin Rouge-ba, minthogy az akkori igazgató magyar származású jóindulatú ember volt, aki sok magyart megvendégelt. Nem lenne-e kedvem velük elmenni? Mondtam, pont aznap érkezik a mamám vonattal. Nem baj, jöjjön ő is, mondta elegáns gesztussal. Mama megérkezett, elvittem a diákszállói szobámba, kicsit kipihente magát, nem mondom, hogy nem szívesebben ment volna az operaházba, de végül is beleegyezett.

Hátul ültünk négyen, de onnan is végig lehetett kísérni ezt az endokrinológiában ugyan nem szereplő programot, ami azért serkentette a nézők trophormonjait. Egyszer egy életben egy endokrinológus is elengedheti magát. Az előadás pazar volt, de észrevettem, hogy mamám feje olykor lekókad. Így aztán - azt hiszem, Guiness-rekordként - egyedüliként hagytuk ott az előadást, amelyért mások sorba álltak. Hát hiába, a magyar endokrinológusok nemcsak a kísérleteknél és a közleményeknél, hanem még ilyen gyanús körülmények között is tudnak újat produkálni.

A fentiekkel hajolok meg azok előtt, akiket tudásukért és emberi magatartásukért tiszteltem és szerettem.

Hankisss János dr., e-mail: hankiss.jeney@t-online.hu

„Ha minden iskolában és családban a könyvben szereplő ötletek kis töredékét felhasználnák, beláthatatlan lehetöségek nyilnának meg elöttünk, hogy javítsuk az autizmussal vagy Asperger-szindrómával élő gyermekek életminőségét. Ez pedig csodálatos dolog!"

A könyv számtalan azonnal alkalmazható ötletet

kínál szülőknek és nevelőknek az alábbi területeken:

- szenzoros integráció: fejlesztőfeladatok a szabadban és bent,

- kommunikáció: szóhasználat, hallás, vizualitás, környezet,

- viselkedés: tipikus viselkedési formák és kezelésük,

- mindennapi élet: ötletek a mindennapi szituációkhoz, a biztonság megteremtéséhez,

- szociális létezés: barátság, játék, kooperáció, érzelmek. 